Krisztina Kun-Bodnár, Zsolt Maros, Miskolc, Hungary

\title{
THEORETICAL DETERMINATION OF REMOVED LAYER DEPTH AT ABRASIVE WATERJET TURNING
}

\begin{abstract}
Abrasive waterjet turning is new technology to machine cylindrical or axisymmetric parts from hard to machine materials. One of the problems of waterjet turning is that the real depth of cut usually is not equal with the adjusted radial depth of cut. Aim of the paper is to develop a mathematical method for determining the real depth of turning. This method is based on the equality of effecting time of the jet at turning and simple kerfing test accomplished by abrasive waterjet.

Keywords: waterjet turning, abrasive waterjet; theoretical model; geometrical characteristics; removed layer; depth of cut.
\end{abstract}

\section{INTRODUCTION}

Abrasive waterjet machining (AWJM) is a new innovative technology to remove material. Methods of this material removed is widening nowadays. One of these new waterjet technologies is the turning with abrasive waterjet: This machining method enables producing axisymmetric parts, eg. cylindrical or conical surfaces from materials which cannot be machined by chip removal methods. In abrasive waterjet turning (AWJT) the workpiece is rotating while the cutting head is moving axially with a defined depth of cut (Fig. 1.)

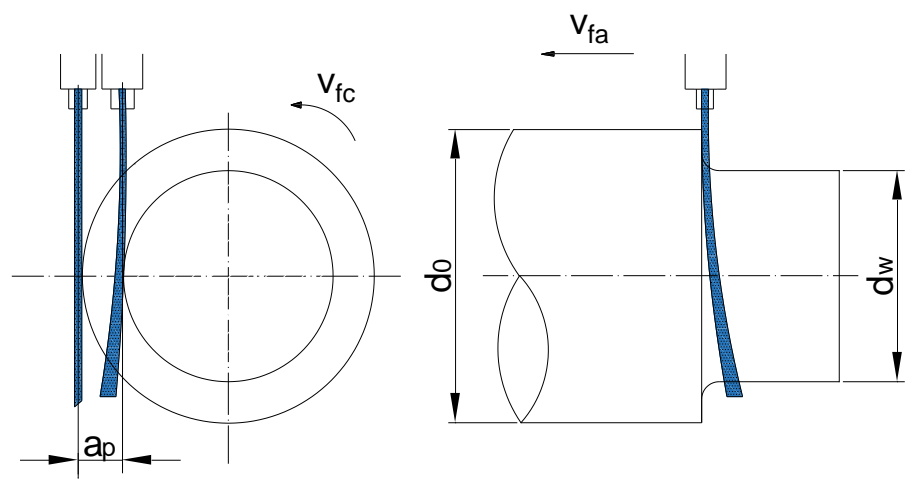

Figure 1 - Cinematic view of abrasive waterjet turning 
The material removal is accomplished by the jet containing abrasive powder, water and air. The cutting forces are very low at waterjet cutting, which gives the possibility to cat parts with long length and relatively small diameter [1] The process is suitable for machining of rigid and difficult to cut materials, like glasses, ceramics, composites and different super- or titanium alloys [2,3,4].

\section{ESSENCE OF MATERIAL REMOVAL AT ABRASIVE WATERJET MACHINING}

The abrasive waterjet consists of three components: water, abrasive grins (powder) and air. The air is absolutely is not useful from point of machining. The material removal accomplished mainly by the abrasive powder. The material removal is a so-called solid erosion by impacts with solid grains (abrasive powder). The abrasive grains have very high speed in the jet, about $500-1000 \mathrm{~m} / \mathrm{s}$, depends on the pressure and the geometry of the cutting head. Depending on the target material characteristics different erosions will be going on. (Fig. 2).

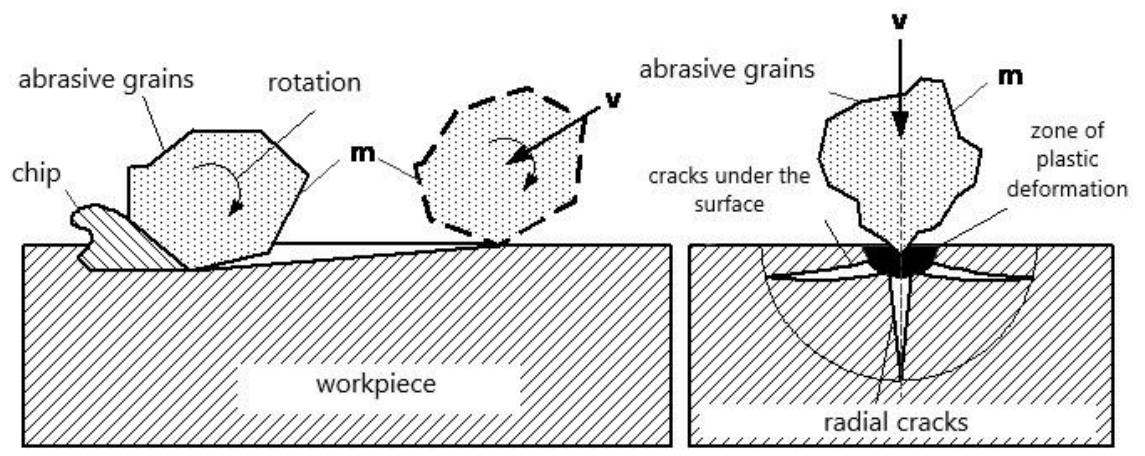

Figure 2 - Ductile and rigid erosion during impact of abrasive grain [5,6]

At ductile erosion material removal is caused by plastic deformation, or ideally by micro machining mechanism (Fig. 2.), removing small chips. At brittle erosion material removal is accomplished with help of crack growth and intersection of cracks. At increasing depth, the jet loses energy which results a deflection of the jet and a change in the material removal process from the cut to the deformation wear. This phenomenon produces a slight roughness to the cut surface called "striations", which are typical of all beam cutting processes. From the side of the material for ductile materials typical parameter is the hardness, for rigid material the fracture properties are the parameters expressing the machinability of the material. 


\section{EFFICIENCY OF THE CUT, DEPTH OF KERF}

When the effect of different parameters on the efficiency is investigated, usually the depth of kerf is the test parameter of the experiments. In this case the material is not cut through and the depth of the kerf (cut) is measured.

There are a lot of technological parameters which effect on the efficiency of waterjet cutting: diameter of the nozzle and the focusing tube, type of abrasive, stand-off-distance, pressure, traverse rate, abrasive mass flow rate etc., but usually researches are focused to investigate the effect of the next process parameters: pressure, traverse speed (feed rate) and abrasive flow.

On base of cutting experiments. the depth of kerf can be determined with different mathematical models. One of the most applied formula is model of Monno [7] was accomplished like mathematical model for determination of depth of kerf:

$$
k=A \frac{p^{B} m_{a}^{C}}{v_{f}}
$$

where $\mathrm{k}$ : the estimated depth of cut

p: $\quad$ pressure, $\mathrm{MPa}$

ma: abrasive mass flow, $\mathrm{g} / \mathrm{min}$

$\mathrm{v}_{\mathrm{f}}$ : $\quad$ traverse feed speed, $\mathrm{mm} / \mathrm{min}$

$\mathrm{A}, \mathrm{B}, \mathrm{C}, \mathrm{D}$ are constants.

The effect of the technological parameters relating (1) can be seen on Fig. 3.

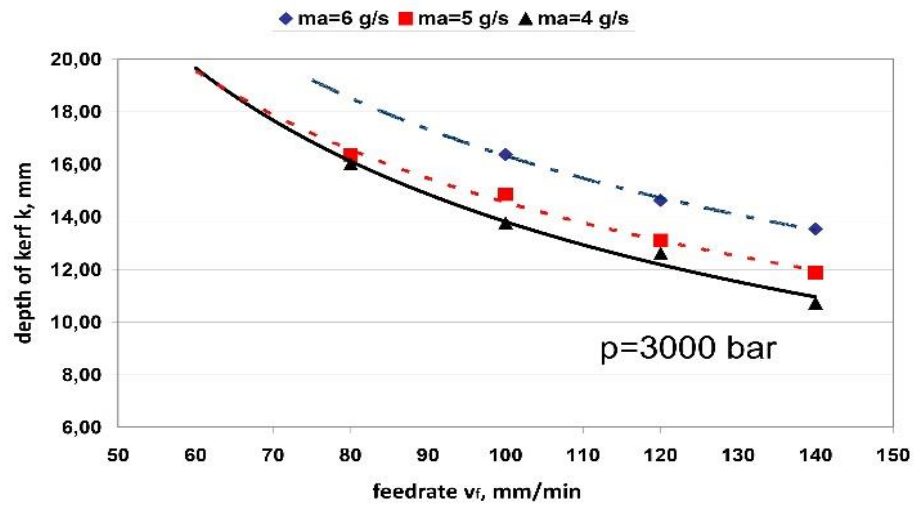

Figure 3 - Effect of the traverse- and the mass flow rate on the depth of cut $(\mathrm{k})$ (material X12Cr13 steel) 
With help of equation (1) and figures - like Fig. 3 - based on cutting experiment, theoretical value of depth of kerf can be estimated.

At a given cut the effecting time (loading time) of the jet for a given point of the workpiece can be calculated from the diameter of the jet and the feed speed:

$$
t_{\text {eff }}=\frac{d}{f}
$$

where teff: the effecting time

d: $\quad$ diameter of the jet

If the effecting times are equal for different cuts, then the depth of kerf determined only by the pressure (p) and the abrasive mass flow rate (ma).

\section{DETERMINATION OF DEPTH OF CUT IN CASE OF WATERJET TURNING}

At abrasive waterjet turning the real depth of cut is not always determined by the position of the jet [8] (Fig. 4).
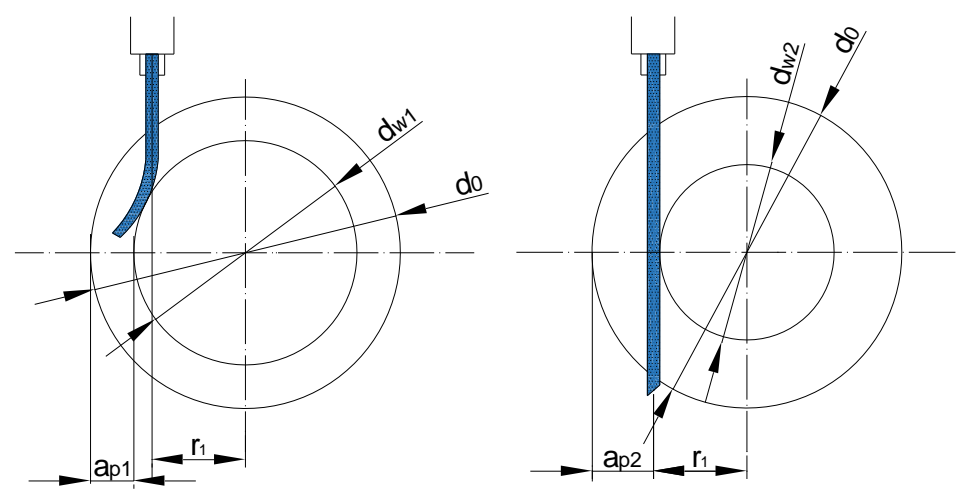

Figure 4 - Geometrical characteristics of waterjet turning

As it can be seen on Fig. 4, the depth of cut $\left(a_{p}\right)$ is not always determined by the radial displacement of the jet $\left(r_{j}\right)$. The depth of cut is determined by the efficiency of the cut, ie. by the depth of kerf $(\mathrm{k})$. This depth depends on the effecting (loading) time ( $\left.\mathrm{t}_{\text {eff }}\right)$, the pressure and the abrasive mass flow rate $\left(\mathrm{m}_{\mathrm{a}}\right)$, if other parameters - like stand of distance (SOD) and diameters of the jet are considered constant. 
If we can determine the effecting time, then result of simple kerfing test can be used for determination of depth of cut at waterjet turning accomplished by given pressure and abrasive mass flow rate.

The abrasive waterjet moves a spiral curve according to the workpiece. One point of the workpiece is attacked by the jet during the effecting time (Fig. 5).

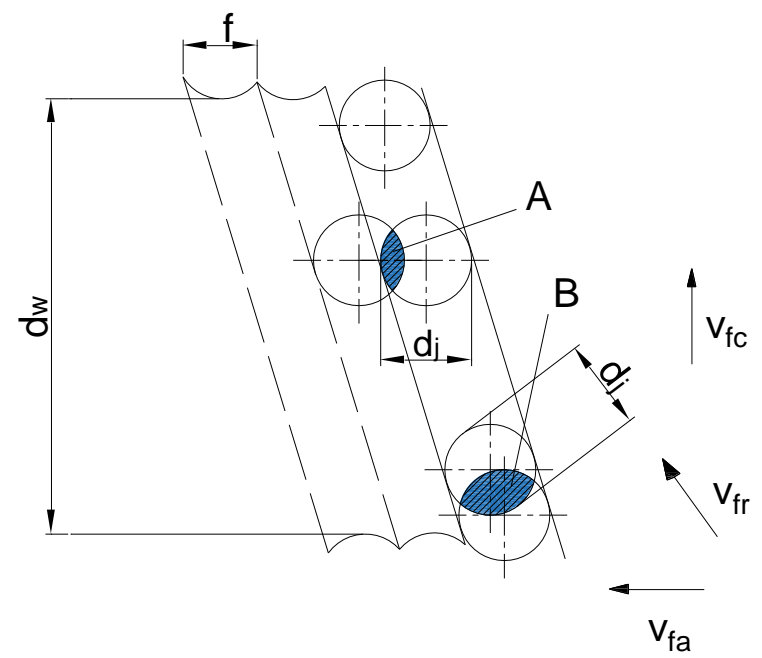

Figure 5 - Geometrical characteristics of waterjet turning

If we determine the effecting time, then for a given pressure and abrasive mass flow rate it is possible to define the extent od the depth of kerf (k) from which the depth of cut can be calculated according to the Fig. 4.

On base of Fig 5 the time in which the jet is in contact with a given point can be determined as follows:

The time, during the jet is contacting with a point along the spiral line (A point):

$$
t_{r}=\frac{d_{j}}{v_{f r}}
$$

where $\mathrm{t}_{\mathrm{r}}$ : the time of contacting along the spiral line

$\mathrm{d}_{\mathrm{j}}$ : the diameter of the jet

$v_{\mathrm{fr}}$ : the resultant feed speed of the jet

the resultant feed speed of the jet: $v_{f r}=\sqrt{v_{f a}^{2}+v_{f c}^{2}}$

where: $v_{\mathrm{fc}}$ : the circular feed speed of the jet 


$$
v_{f e}=d_{w} \pi \mathrm{m}
$$

where: $\mathrm{n}: \quad$ the number of rotations of the workpiece

$\mathrm{v}_{\mathrm{fa}} \mathrm{a} \quad$ the adjusted resultant feed speed of the jet

The time for a rotation of the jet around the circle of the workpiece (B point):

$$
t_{c}=\frac{1}{n}
$$

In axial direction the jet is in contact with a point of the workpiece:

$$
t_{a}=\frac{d_{j}}{v_{f a}}
$$

During this time the jet is turning back more times to the same workpiece point. This number of turning back is:

$$
N=\frac{t_{a}}{t_{c}}
$$

Finally, the effecting time to one given point of the workpiece:

$$
t_{\text {eff }}=N t_{r}
$$

Summarising the (3)-(9) equations we have got:

$$
t_{e f f}=\frac{d_{j}^{n} n}{v_{f a} v_{f Y}}
$$

After determining the effecting time, from the kerfing tests mentioned in section 3, the extent of the kerf $(\mathrm{k})$ can be estimated. From the kerf the real depth of cut $\left(a_{p}\right)$ can be easy to calculate on geometrical base of Fig. 3. With help of the real depth of cut the machined workpiece diameter $\left(\mathrm{d}_{\mathrm{w}}\right)$ can be determined

\section{ACKNOWLEDGEMENT}

"The described study was carried out as part of the EFOP-3.6.1-16-00011 "Younger and Renewing University - Innovative Knowledge City - institutional development of the University of Miskolc aiming at intelligent specialisation" project implemented in the framework of the Szechenyi 2020 program. The realization of this project is supported by the European Union, co-financed by the European Social Fund."

References: 1. Мапи $R$ - Babu NR: An erosion-based model for abrasive waterjet turning of ductile materials. Wear., 2009; 266: 1091-7. 2. Axinte DA - Stepanian JP - Kong MC - McGourlay J: Abrasive waterjet turning - An efficient method to profile and dress grinding wheels. International Journal of MachineTools \& Manufacture. 2009; 49: 351-6. 3. Kovacevic $R$ - Hashish M - Mohan R - Ramulu M Kim TJ - Geskin ES: State of the art of research and development in abrasive waterjet machining. 
ASME Journal of manufacturing Science and Engineering. 1997; 119: 776-85. 4. Mazurkiewicz M: A manufacturing tool for a new century. Journal of Materials Processing Technology. 2000; 106: 112-8. 5. Finnie, I.: The Mechanism of Erosion of Ductile Metals, Proceedings of 3th US Nat. Congress Applied Mechanics, ASME New York 1958, pp527-532 6. Buijs, M.: Erosion of Glass as Modeled by Indentation Theory, Journal of American Ceramic Society 77, 1994, pp1676-1678 7. Brandt, S. - Maros, Zs. - Monno, M.: AWJ Parameters Selection - a Technical and Economical Evaluat 8 ion, 15th International Conference on Jetting Technology, Ronneby, Sweden, 6-8 September 2000., pp353-366 8. Zohoor $M$ - Zohourkari I - Cacciatore $F$ - Annoni $M$ : Influence of machining parameters on part geometrical error in abrasive waterjet offset-mode turning, Proceedings of the Institution of Mechanical Engineers, Part B: Journal of Engineering Manufacture, 2014 Volume: 229 issue: 12, pp 2125-2133.

\title{
Крістіна Кун-Боднар, Жолт Марош, Мішкольц, Угорщина
}

\section{ТЕОРЕТИЧНЕ ВИЗНАЧЕННЯ ВЕЛИЧИНИ ВИДАЛЕНОГО ШАРУ ПРИ АБРАЗИВНО-СТРУМЕНЕВОМУ ТОКАРНОМУ ОБРОБЛЯННІ}

\begin{abstract}
Анотація. Абразивно-струменева токарна обробка - це нова технологія для обробки ииліндричних або осесиметричних деталей від твердих до конструкиійних матеріалів. Одна із проблем гідроабразивного токарного обробляння полягає в тому, що реальна глибина різання зазвичай не дорівнює скоригованій радіальній глибині різання. Метою роботи є розробка математичного методу визначення реальної глибини прорізу. Цей метод заснований на рівності часу впливу струменя на зняття припуску і простому випробуванні на переріз, виконаному абразивно-рідинним струменем. Видалення матеріалу здійснюється струменем, що містить абразивний порошок, воду і повітря. Зусилля різання дуже малі при гідроабразивному різанні, шо дає можливість обробляти деталі великої довжини і відносно невеликого діаметру. Цей проиес підходить для обробки жорстких і важкооброблюваних матеріалів, таких як скло, кераміка, композити і різні надтверді матеріали або титанові сплави. Як показують дослідження, глибина різання не завжди визначається радіальним зміщенням струменю. Глибина різання визначається ефективністю різання, тобто по глибині пропилу. Ця глибина залежить від часу впливу, тиску і абразивної масової витрати, якщо інші параметри, такі як відстань від сопла $i$ діаметр струменя, вважаються постійними. Якщо ми можемо визначити час дії, то результат простого тесту на пропил може бути використаний для визначення глибини різання при абразивно-струменевій обробці, яка виконується з заданим тиском і масовоє витратою абразиву. Після визначення часу впливу, виходячи з випробувань на прорізь, можна очінити ступінь прорізу. 3 прорізу реальна глибина різання може бути легко розрахована на геометричній основі. За допомогою реальної глибини різання можна визначити діаметр оброблюваної деталі.
\end{abstract}

Ключові слова: гідроабразивне точіння; гідроабразивний; теоретична модель; геометричні характеристики; знятий шар; глибина різанняю. 